\title{
The Water Quality Changes and Economic Benefit Analysis of Polyculture of Panopea Generosa with Marine Fishes in Pond
}

\author{
Z. Q. WANG , X. X. WANG , Y. X. WANG, C. X. SUN \\ Shandong Marine Resource and Environment Research Istitute, Yantai, China
}

X. L. YANG

Ocean School, Yantai University, Yantai, China

\begin{abstract}
In order to explore the impact on water quality and economic benefit of polyculture mode, bred Panopea generosa with Oncorhynchus mykiss, Pseudopleuronectes yokohamae, Acanthopagrus schlegelii, Sebastodes fuscescens and Scophthalmus maximus in outdoor pond from March to May 2013 in Penglai Zongzhe Breeding Co. Ltd.. The results showed that: The water quality factors $\left(\mathrm{NH}_{4}{ }^{+}-\mathrm{N}, \mathrm{NO}_{2}{ }^{-}-\mathrm{N}, \mathrm{NO}_{3}{ }^{-} \mathrm{N}\right.$, $\mathrm{COD}, \mathrm{DO})$ were in line with nuisanceless water quality standards; Water temperature in pond was $3 \sim 7{ }^{\circ} \mathrm{C}$ higher than natural water due to adopting indoor circulated water technology, which speeded up the growth of fishes; The output value reached 2.0337 million yuan after nearly 20 months of cultivation, the total profit and unit profit was 757, 900 yuan and 126, 300 yuan/acre respectively; The ratio of investment on output value was 1:1.594, so the company won $59.41 \%$ of economic benefit. Polyculture effect of Panopea generosa and marine fishes was well.
\end{abstract}

KEYWORD: Panopea generosa; marine finfish; polyculture; water quality; economic benefit

\section{INTRODUCTION}

Panopea generosa is an important large-scale shellfish in the Pacific coast of North America, which belongs to Panopea, Hiatellidae, Myoidae, Bivalvia,Mollusca (Liu, M. K. et al. 2013). Panopea generosa has high economic efficiency with the characteristics of fresh meat, high nutritional value and rapid growth.

In recent years, there have been many studies shown that the polyculture mode of fish and mussel has significant improvement for farming water quality. The polyculture system of feeding fish and hanging mussel can effectively improve water quality and increase the survival rate of fish $(\mathrm{Hu}, \mathrm{M}$. H. et al. 2013). The algae in pond is not only a major source of primary productivity of water, but also the main food of filter-feeding shellfish, shellfish has direct filter-feeding and indirect inhibition effects, as well as feedback mechanism on plankton $(\mathrm{Lu}, \mathrm{J}$. R. et al. 1997). In this study, we researched the impact of polyculture mode of fish and Panopea generosa in pond on water quality and analyze its economic benefit through experiment.

\section{MATERIALS AND METHODS}

\subsection{Experimental design}

This experiment was conducted in a 6 acre outdoor pond with an average depth 3.8 meter in Penglai Zongzhe Breeding Co. Ltd.. The water source of this pond was mainly from the indoor farming plant of Scophthalmus maximus which more than $20000 \mathrm{~m}^{2}$. There were 5 kinds of marine fish, including Oncorhynchus mykiss, Pseudopleuronectes yokohamae, Acanthopagrus schlegelii, Sebastodes fuscescens and Scophthalmus maximus. Moving Panopea generosa into pond on March 11, 2013, divided two farming methods of breeding cage and breeding box, which were moved out on June 5, 2013 and June 7, 2013 respectively.

\subsection{Sample collection and methods}

Setting 4 sampling points, sampling point 1 was located outside the pond for the outfall of the 1st indoor workshop, where the water had not yet entered the pond; sampling point 2 was located at the connection of the pond and the outfall of No. 2 indoor workshop; sampling point 3 was located in the center of the pond; sampling point 4 was located at the outfall of the pond.

We collected surface water once about seven days and measured their $\mathrm{pH}, \mathrm{COD}$, dissolved oxygen, 
ammonia nitrogen, nitrate nitrogen and nitrite nitrogen according to the national standard. Phytoplankton samples were collected by a $5 \mathrm{~L}$ water harvesting and then fixed by Lugol reagents. After $24 \mathrm{~h}$ settlement, concentrated to $50 \mathrm{~mL}$ and counted cell amount, estimated biomass of phytoplankton by cell volume method. Randomly collected 30 to 50 Panopea generosa of breeding cage and breeding box respectively during each sampling, measured their shell length and body weight.

\section{RESULTS AND DISCUSSION}

\subsection{Results of physic-chemical parameters}

\subsubsection{COD}

Measurement range of COD was from $1.17 \mathrm{mg} / \mathrm{L}$ to $7.64 \mathrm{mg} / \mathrm{L}$, the variation width of COD in all sampling points was tiny in addition to April 23 (Figure 1). The pond has taken measures of often irrigation and drainage due to the large amount of water from the indoor pool. The COD of the sampling points in pond was lower than the sampling point outside the pond in March, while higher than outside the pond in April and May.

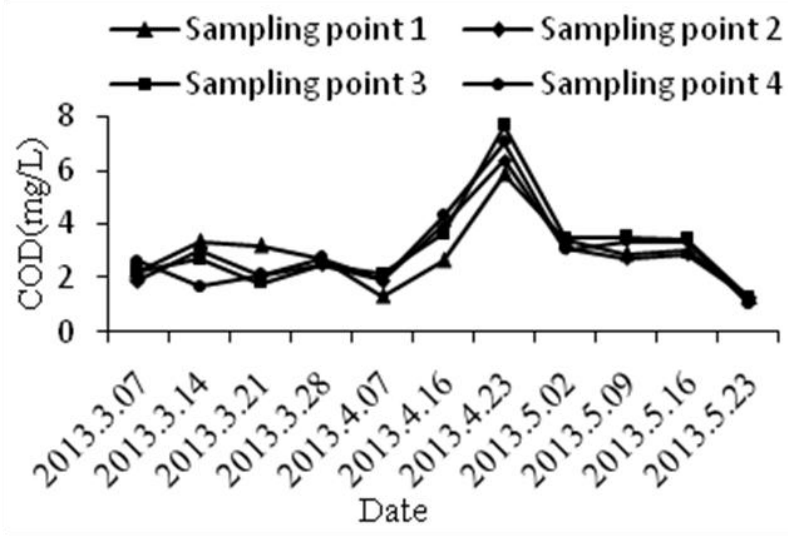

Figure 1 Changes curve of COD

\subsubsection{Ammonia nitrogen}

Ammonia in water was shown in Figure 2, the ammonia concentration varied from $0.023 \mathrm{mg} / \mathrm{L}$ to $0.3 \mathrm{mg} / \mathrm{L}$ and fluctuated around $0.15 \mathrm{mg} / \mathrm{L}$. The concentration of ammonia was low and steady in sampling point 1, while fluctuated in the three sampling points in pond and presented a peak each month, however the peak decreased monthly. Experimentally measured ammonia was the sum of $\mathrm{NH}_{4}^{+}{ }_{4} \mathrm{~N}$ and $\mathrm{NH}_{3}-\mathrm{N}, \mathrm{NH}^{+}{ }_{4}-\mathrm{N}$ was nontoxic nutrient, however $\mathrm{NH}_{3}-\mathrm{N}$ was highly toxic to aquatic organisms. The present form of total ammonia was related to $\mathrm{pH}$ of water. The simultaneous measurement results of $\mathrm{pH}$ ranged from 7.09 to 8.03 (Table 1), in this case, about $95 \%$ of total ammonia was $\mathrm{NH}_{4}^{+} \mathrm{N}$, what was more, total ammonia of farming water generally required $0.5 \mathrm{mg} / \mathrm{L}$ or less, so that ammonia in this pond was safe.

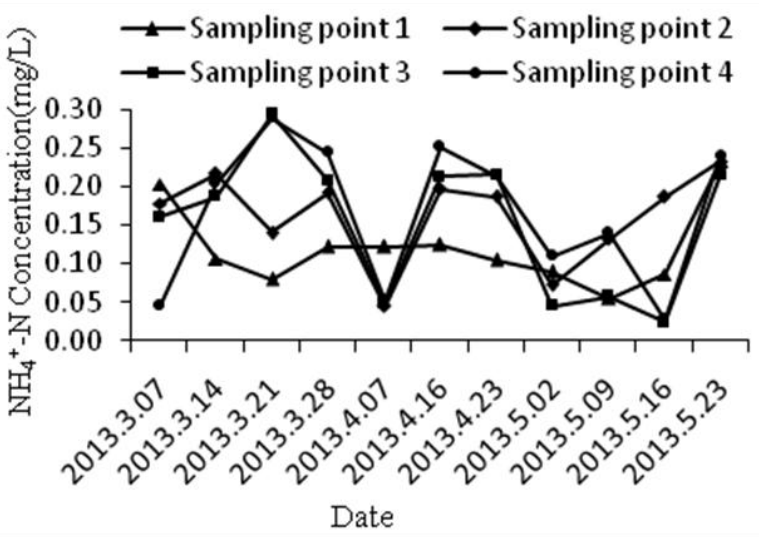

Figure 2 Changes curve of ammonia nitrogen concentration

Table 1 Result of $\mathrm{pH}$ in the pond water

\begin{tabular}{|c|c|c|c|c|}
\hline \multirow{2}{*}{ Date } & \multicolumn{4}{|c|}{ Sampling point } \\
\cline { 2 - 5 } & 1 & 2 & 3 & 4 \\
\hline 2013.3 .07 & 7.09 & 7.28 & 7.33 & 7.38 \\
\hline 2013.3 .14 & 7.72 & 7.76 & 7.62 & 7.64 \\
\hline 2013.3 .21 & 7.65 & 7.64 & 7.72 & 7.76 \\
\hline 2013.3 .28 & 7.59 & 7.57 & 7.64 & 7.76 \\
\hline 2013.4 .16 & 7.34 & 7.76 & 7.78 & 7.79 \\
\hline 2013.4 .23 & 7.61 & 8.02 & 8.03 & 7.85 \\
\hline 2013.5 .02 & 7.5 & 7.71 & 7.96 & 7.89 \\
\hline 2013.5 .09 & 7.61 & 7.62 & 7.82 & 7.78 \\
\hline 2013.5 .16 & 7.49 & 7.53 & 7.91 & 7.82 \\
\hline 2013.5 .23 & 7.50 & 7.50 & 7.46 & 7.51 \\
\hline
\end{tabular}

\subsubsection{Nitrate nitrogen}

The concentration of nitrate ranged from $0.042 \mathrm{mg} /$ $\mathrm{L}$ to $0.81 \mathrm{mg} / \mathrm{L}$ and appeared the peak in sampling point 4 at May 2 as shown in Figure 3. Most of the time, $\mathrm{NO}^{-}-\mathrm{N}$ concentration of the three sampling points in pond was higher than the number of sampling point 1 outside the pond due to ammonia and nitrite nitrogen were converted to $\mathrm{NO}^{-}-\mathrm{N}$, which showed the amount of dissolved oxygen in the pond water was higher (Table 2).

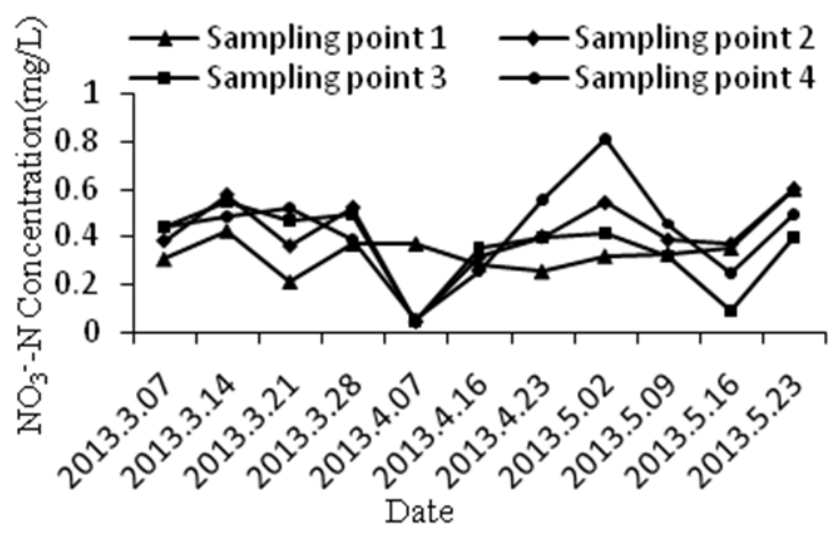

Figure 3 Changes curve of nitrate nitrogen concentration 
Table 2 Result of dissolved oxygen in the pond water $(\mathrm{mg} / \mathrm{L})$

\begin{tabular}{|c|c|c|c|c|}
\hline \multirow{2}{*}{ Date } & \multicolumn{4}{|c|}{ Sampling point } \\
\cline { 2 - 5 } & 1 & 2 & 3 & 4 \\
\hline 2013.3 .07 & 4.56 & 5.70 & 6.72 & 7.71 \\
\hline 2013.3 .14 & 5.60 & 6.03 & 6.22 & 6.49 \\
\hline 2013.3 .21 & 5.33 & 5.81 & 6.58 & 6.62 \\
\hline 2013.3 .28 & 5.64 & 6.38 & 7.34 & 6.72 \\
\hline 2013.4 .07 & 6.10 & 8.16 & 8.20 & 7.47 \\
\hline 2013.4 .16 & 6.19 & 6.30 & 6.52 & 6.61 \\
\hline 2013.4 .23 & 6.32 & 8.96 & 10.64 & 10.73 \\
\hline 2013.5 .02 & 5.24 & 9.60 & 10.58 & 8.30 \\
\hline 2013.5 .09 & 6.62 & 7.92 & 10.15 & 8.67 \\
\hline 2013.5 .16 & 5.93 & 6.40 & 10.58 & 7.92 \\
\hline
\end{tabular}

\subsubsection{Nitrite nitrogen}

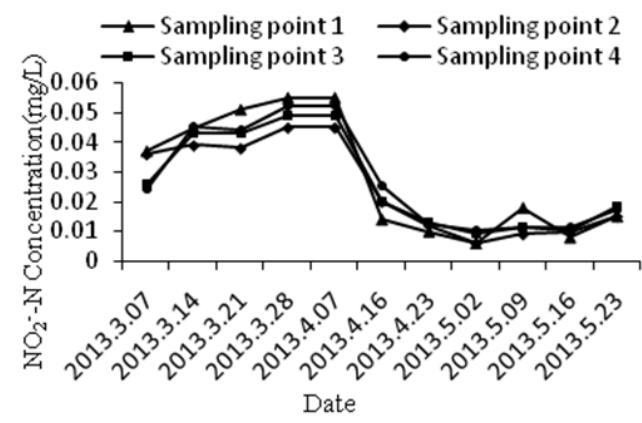

Figure 4 Changes curve of nitrite nitrogen concentration

As shown in Figure 4, nitrite concentration ranged from $0.006 \mathrm{mg} / \mathrm{L}$ to $0.055 \mathrm{mg} / \mathrm{L}$. The organic matter excreted by physiological metabolism of indoor farmed fish increased the concentration of nitrite in the pond water, thus making the nitrite concentration of indoor water higher than pond water in March, but lower in April and May. Therefore, outdoor pond played a role in the degradation of $\mathrm{NO}_{2}^{-}-\mathrm{N}$.

\subsubsection{Temperature}

The temperature of indoor recycled water in pond was $3 \sim 7{ }^{\circ} \mathrm{C}$ higher than the natural water (Figure $5)$. The water temperature in pond was within the suitable temperature range for the growth of five kinds of fish(Sun, Y. et al. 2001; Li, Y. et al. 2011). The rise of water temperature speeded up the growth of fish.

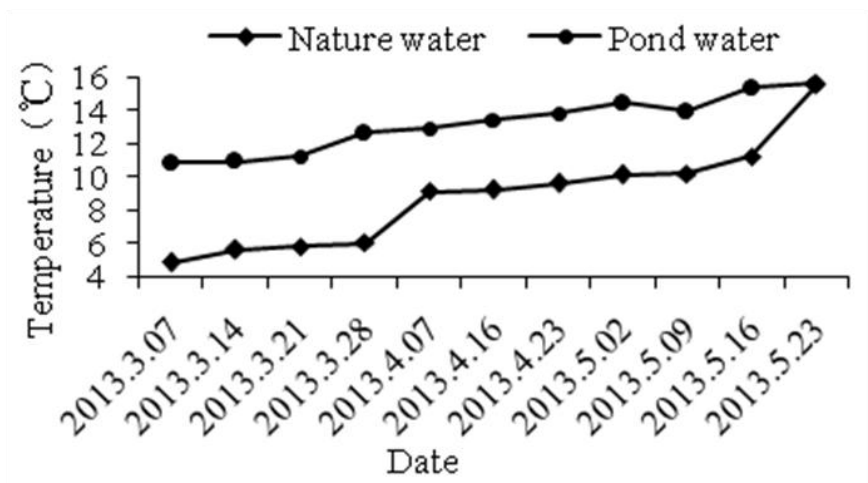

Figure 5 Changes curve of temperature

\subsection{Farming results of fish}

\subsubsection{Stocking quantity and net production}

Oncorhynchus mykiss, Pseudopleuronectes yokohamae, Acanthopagrus schlegelii, Sebastodes fuscescens and Scophthalmus maximus were stocked to outdoor pond on October 1, 2011. The stocking quantity and net production of five kinds of fish were in Table 3. The net production of Oncorhynchus mykiss, Pseudopleuronectes yokohamae, Acanthopagrus schlegelii, Sebastodes fuscescens and Scophthalmus maximus were 19520 $\mathrm{kg}, \quad 3225 \mathrm{~kg}, \quad 2937.5 \mathrm{~kg}, \quad 5737.5 \mathrm{~kg}$ and $7950 \mathrm{~kg}$ respectively.

Table 3 Stocking quantity and net production of five kinds of fish in outdoor pond

\begin{tabular}{|l|c|c|c|c|c|}
\hline Breeding species & Fry fish weight (g) & Stocking quantity & Survival rate & Adult fish weight (g) & Net production (kg) \\
\hline Oncorhynchus mykiss & 150 & 8000 & $80 \%$ & 3200 & 19520 \\
\hline $\begin{array}{l}\text { Pseudopleuronectes } \\
\text { yokohamae }\end{array}$ & $10-15$ & 10000 & $60 \%$ & 550 & 3225 \\
\hline Acanthopagrus schlegelii & $10-15$ & 10000 & $50 \%$ & 600 & 2937.5 \\
\hline Sebastodes fuscescens & $10-15$ & 10000 & $90 \%$ & 650 & 5737.5 \\
\hline Scophthalmus maximus & $10-15$ & 15000 & $80 \%$ & 675 & 7950 \\
\hline
\end{tabular}

\subsubsection{Economic benefit analysis}

Main investment of this pond included fish fry, feed, oxygen equipment, utilities, labor and rent fees. Total fry fees of five kinds of fish were 155,500 yuan. The yield of fish was calculated according to their net production; Feed fees of Oncorhynchus mykiss, Pseudopleuronectes yokohamae, Acanthopagrus schlegelii and Sebastodes fuscescens were 236,200 yuan, 39,000 yuan, 35,500 yuan and
69,400 yuan respectively basised on feed conversion ratio by 1.1 and feed unit price by 11 yuan / kg; Scophthalmus maximus costed for 100,200 yuan basised on feed conversion ratio by 1.05 and feed unit price by 12 yuan / $\mathrm{kg}$. In addition, fees of utilities, labor, rent and so on were 640,000 yuan. Total investment of this pond was 1.2758 million yuan. 
Output value of five kinds of fish was calculated by their net production and the price when they out of the pond. The price of Oncorhynchus mykiss and Acanthopagrus schlegelii was 60 yuan / kg; the price of Pseudopleuronectes yokohamae and Scophthalmus maximus was 46yuan / kg; the price of Sebastodes fuscescens was 30yuan / kg. Therefore, the total output value of the pond was 2.0337 million yuan.

The total profit of the pond with 6 acres was 757,900 yuan, so the unit profit was 126,300 yuan / acre for 20-month. The result of economic analysis of the outdoor pond: The ratio of investment on output value was 1:1.594; economic benefit (profit on investment ratio) was $59.41 \%$.

\subsection{Breeding effect of Panopea generosa}

Panopea generosa indoor with average shell weight $16.43 \mathrm{~g}$ and shell length $3.30 \mathrm{~cm}$ was migrated into polyculture pond of fish and divided two kinds of farming form of breeding cage and breeding box on March 11, 2013. Breeding cage and breeding box were moved out on June 5, 2013 and June 7, 2013 respectively. Results of the two farming forms are shown in Figure 6. Preliminary experiment, the shell length of Panopea generosa in breeding box was significantly higher than that in breeding cage ( $\mathrm{P}$ $<0.05$ ), which was due to the buried habitat types of Panopea generosa. Panopea generosa was buried in the sand about $5 \mathrm{~cm}$ thick in breeding box, this mode simulated the growth condition in natural sea and helped to improve the survival rate by avoiding predators.

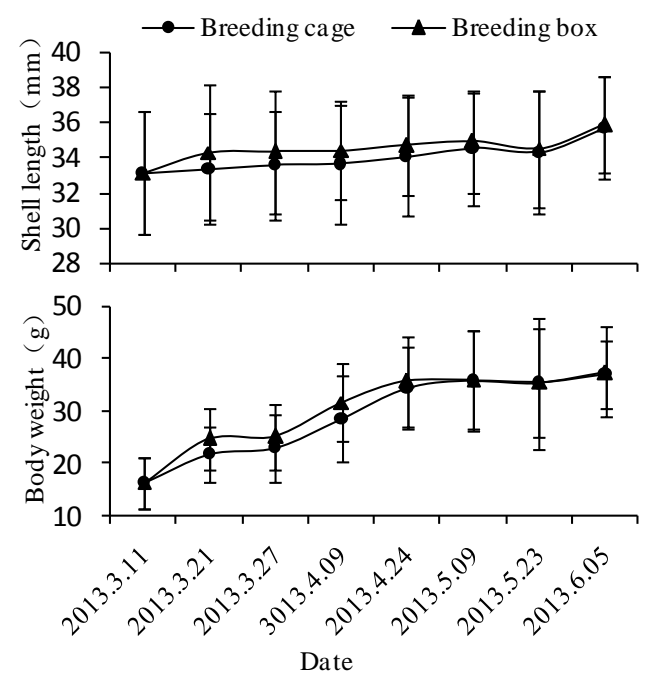

Figure 6 Shell length and body weight of Panopea generosa breeded by two forms

\section{CONCLUSION}

The water quality factors of polyculture of Panopea generosa with marine fishes in pond were in line with nuisanceless water quality standards. Due to the management techniques of reuse technology of indoor cycling water, increasing oxygen technology, often irrigation and drainage technology and so on, this pond could reduce $\mathrm{NO}^{-}-\mathrm{N}$ concentration of indoor water and accelerate the growth of fishes. After nearly 20 months of cultivation, output value reached 2.0337 million yuan including 757,900 yuan of profit. The ratio of investment on output value was $1: 1.594$, so the company won $59.41 \%$ of the economic benefits. Panopea generosa growed well in the case of adding probiotics and did not feed any food. Polyculture with fishes and mussel was an ecological mode by making nitrogen - phytoplankton - Panopea generosa a multi-level nutrition, therefore, increased the economic and ecological benefits of the pond.

\section{ACKNOWLEDGEMENTS}

The authors would like to thank everyone involved in sampling surveys and analysis, and the re-viewers for their helpful comments and suggestions. This research was supported by Major Agricultural Applied and Creative Program of Shandong Provincial Department of Finance"The large-scale indoor aquaculture of Panopea generosa"(20122014), Investigation and Evaluation Project"Investigation and evaluation of spawning grounds in Yellow Sea and Bohai Sea", Public Science and Technology Research Funds Projects of Ocean (No. 201205025).

\section{REFERENCES}

[1] Hu, M. H., Wu, Z., Zhou, Z. Q. \& Liu, Q. G. 2014. The impact of polyculture of freshwater mussel on water quality, plankton community and mussel growth performance in ponds of silver carp and bighead carp. Journal of Fisheries of China38 (2): 200-207.

[2] Liu, M. K., Wang, C. B., Kong, L. F. \& Li, Q. 2013. Studies on artificial reproduction of the Pacific geoduck Panopea generosa. Marine Sciences 37 (8): 103-106.

[3] Li, Y., Sun, G. X., Liu, Y., Gao, T. T., Yu, K. S. \& Liu, J. L. 2011. Effects of temperature on feed intake, growth and digestive enzyme activity of turbot Sco phthatmus maximus L.in high stocking density of closed recirculationg aquaclture system. Progress in Fishery Sciences32 (6): 17-24.

[4] Lu, J. R., Li, D. S., Yang, H. S., Xu, N. \& Zhang, H. Y. 1997. Interactions between plankton and shellfish in fish shellfish polyculture ecosystem of fertilized seawater pond. Journal of Fisheries of China21 (2): 158-164.

[5] Sun, Y., Zhang, B., Guo, X. W., Wang, J. \& Tang, Q. S. 2001. Effects of temperature on energy budget of Sparus macrocephalus. Acta Ecologica Sinica21 (2): 186-190. 